\title{
Effect of white clover (Trifolium repens L.) intercropping system on weed infestation of willow (Salix viminalis L.)
}

\section{Wpływ uprawy współrzędnej koniczyny białej (Trifolium repens L.) na zachwaszczenie wierzby wiciowej (Salix viminalis L.)}

Waldemar Helios

\section{Summary}

The field experiment was conducted in 2010-2012, on the fields of the Department of Crop Production in Pawłowice, belonging to the Wrocław University of Environmental and Life Sciences. The objective of the studies was to determine the effect white clover on weed infestation of three clon willow. The results showed that intercropping system significantly decreased the number of species and dry weight of weeds in comparison with the weed infestation in the pure stand of willow.

Key words: intercropping, willow, white clover, weed infestation

\section{Streszczenie}

Doświadczenie polowe przeprowadzono w latach 2010-2012, na polach Katedry Szczegółowej Uprawy Roślin w Pawłowicach, należących do Uniwersytetu Przyrodniczego we Wrocławiu. Celem badań było określenie wpływu koniczyny białej na zachwaszczenie trzech klonów wierzby wiciowej. W uprawie współrzędnej zaobserwowano mniejszą liczbę gatunków chwastów i ich suchą masę w porównaniu do zachwaszczenia obserwowanego w wierzbie uprawianej bez koniczyny białej.

Słowa kluczowe: uprawa współrzędna, wierzba, koniczyna biała, zachwaszczenie

Uniwersytet Przyrodniczy we Wrocławiu

Katedra Szczegółowej Uprawy Roślin

PI. Grunwaldzki 24A, 50-363 Wrocław

waldemar.helios@up.wroc.pl 


\section{Wstęp / Introduction}

W związku z ociepleniem klimatu wzrasta zainteresowanie pozyskiwaniem nowych, alternatywnych dla węgla, gazu czy ropy naftowej źródeł energii (Miziniak 2008). Ważną rolę w tym zakresie mogą spełniać rośliny uprawne, wśród których jedną z ważniejszych jest wierzba wiciowa (Wojciechowski i wsp. 2011).

Podstawowym warunkiem uzyskania wysokich i dobrej jakości plonów tej rośliny jest utrzymanie plantacji wolnej od chwastów (Skrzypczak i wsp. 2009), zwłaszcza w pierwszych latach po posadzeniu (Trąba i wsp. 2007; Miziniak 2008). Regulacja zachwaszczenia poprzez stosowanie zabiegów mechanicznych i ochronę chemiczną jest ograniczona i utrudniona (Korniak 2007; Trąba i wsp. 2007). Mechaniczna pielęgnacja uszkadza i redukuje korzenie, a zmniejszanie szerokości roboczej maszyn obniża skuteczność odchwaszczania (Szczukowski i wsp. 1996; Skrzypczak i wsp. 2009). Wierzba wykazuje dużą wrażliwość na niektóre substancje czynne w okresie rozwijania pączków i listnienia, a więc wtedy, kiedy zaleca się stosowanie środków chwastobójczych (Trąba i wsp. 2007; Miziniak 2008).

Celem doświadczeń była ocena wpływu koniczyny białej na zachwaszczenie i wysokość roślin wierzby w trzech pierwszych latach po założeniu plantacji.

\section{Materiały i metody / Materials and methods}

Badania polowe przeprowadzono w latach 2010-2012 na polach Katedry Szczegółowej Uprawy Roślin w Pawłowicach, należących do Uniwersytetu Przyrodniczego we Wrocławiu, na glebie lekkiej definiowanej jako mada rzeczna bardzo lekka na piasku luźnym i żwirze piaszczystym.

Doświadczenie na dwa czynniki zmienne założono w układzie split plot w czterech powtórzeniach. Czynnikiem I-rzędu był sposób uprawy wikliny: a) bez koniczyny białej, b) z koniczyną białą (wsianą ręcznie w ilości $10 \mathrm{~kg} /$ ha podczas zakładania plantacji). Czynikiem II rzędu były trzy klony wierzby wiciowej: 1047, 1052, 1057. Przedprzedplonem była gorczyca biała, a przedplonem był ugór. Dominującymi gatunkami chwastów w roku poprzedzającym założenie plantacji były: Echinochloa crus-galli (L.) P. Beauv. oraz Elymus repens (L.) Gould. W lipcu i wrześniu 2009 r. zastosowano 2-krotny oprysk herbicydem Roundup 360 SL w dawce 5 1/ha oraz wykonano jesienną orkę. Wiosną wyrównano pole agregatem uprawowym. Po tych zabiegach nie zwalczano już chwastów do końca prowadzonych badań. Corocznie stosowano nawożenie w dawkach $40 \mathrm{~kg} \mathrm{P}_{2} \mathrm{O}_{5}$ i $60 \mathrm{~kg} \mathrm{~K} 2 \mathrm{O}$ na hektar. Nie stosowano nawożenia azotowego. Wierzbę posadzono na początku kwietnia 2010 r. w międzyrzędziach o szerokości $65 \mathrm{~cm}$ i odległości roślin $\mathrm{w}$ rzędzie $40 \mathrm{~cm}$ (38,5 tys. zrzezów na ha). Powierzchnia poletek do zbioru wynosiła $6,76 \mathrm{~m}^{2}$. Nie przycinano roślin wierzby po pierwszym roku wegetacji i nie koszono koniczyny w okresie prowadzenia badań. Co roku w czerwcu i wrześniu określano zachwaszczenie metodą ramkową na każdym poletku w 4 losowo wybranych miejscach o powierzchni $0,25 \mathrm{~m}^{2}$. Ozna- czano gatunki i liczbę chwastów oraz ich świeżą masę i zawartość wody. Średni stopień pokrycia gleby przez wszystkie chwasty określono metodą wizualną podczas ich liczenia. Wysokość wierzby mierzono corocznie pod koniec okresu wegetacyjnego na 10 roślinach z każdego poletka. Zbiór świeżej masy wykonano w marcu 2013 roku.

\section{Wyniki i dyskusja / Results and discussion}

W doświadczeniu stwierdzono występowanie od 3 do 17 gatunków chwastów (tab. 1, 2). Podobne wyniki uzyskał Sowiński (1988), który wykazał 20 taksonów. Zdecydowanie większą różnorodność gatunkową zaobserwowali Korniak (2007) oraz Rola i wsp. (2007). Z dostępnej literatury wynika, że skład gatunkowy i liczbę chwastów na $1 \mathrm{~m}^{2}$ kształtują lokalne warunki przyrodnicze, gatunek rośliny uprawnej oraz czynniki agrotechniczne (Rola i wsp. 2006). Przeprowadzone badania wykazały, że średni stopień pokrycia gleby przez chwasty na poletkach kontrolnych zmniejszył się od 35\% w 2010 r. do 25\% w 2012 r., a w uprawie współrzędnej z koniczyną białą nie przekraczał $15 \%$. Wraz ze wzrostem wierzby wypadały światłolubne jednoroczne gatunki segetalne, a pojawiały się gatunki wieloletnie (tab. 1, 2). Podobnie Trąba i wsp. (2007) wykazali, że w składzie gatunkowym chwastów na plantacjach Salix sp. w latach późniejszych dominują taksony wieloletnie nad krótkotrwałymi.

We wszystkich latach badań na poletkach w uprawie współrzędnej zaobserwowano mniejszą w porównaniu do kontroli liczbę gatunków chwastów (tab. 1, 2).

Koniczyna biała okazała się też przydatną żywą ściółką w uprawie pora (Winiarska i Kołota 2004). W badaniach własnych najczęstszym niepożądanym gatunkiem w uprawie współrzędnej był E. repens (tab. 3, 4). W kolejnych latach badań zmieniał się skład gatunkowy i liczba chwastów na $1 \mathrm{~m}^{2}$. W 2010 r., w czerwcu przeważały siewki E. crus-galli, Setaria glauca (L.) P. Beauv. oraz Chenopodium album L. (tab. 3). We wrześniu zaobserwowano rośliny Galinsoga parviflora Cav. (tab. 4). W kontrolnej dwuletniej wiklinie nie pojawiły się: Thlaspi arvense L., Anagallis arvensis L., Galinsoga parviflora oraz zmniejszyła się liczba roślin Polygonum lapathifolium L. i E. crus-galli. Zwiększył się udział E. repens oraz zaobserwowano dużo siewek Conyza canadensis (L.) Cronquist (tab. 3).

W maju pojawiła się Vicia hirsuta (L.) S. F. Gray, a w późniejszych miesiącach stwierdzono obecność Taraxacum officinale F. H. Wigg. oraz nielicznych osobników Solidago virgaurea L. i Artemisia vulgaris L. W trzecim roku badań zwiększyła się liczba roślin E. repens i Taraxacum officinale oraz pojawiły się nieliczne rośliny: Achillea millefolium L., Populus alba L. i Chamerion angustifolium (L.) Holub. Nie stwierdzono obecności E. crus-galli i P. lapathifolium.

Od 2010 do 2012 r. malała sucha masa chwastów w czerwcu i wrześniu oraz ich liczba we wrześniu. Zawartość wody w roślinach niepożądanych była wyższa w czerwcu niż we wrześniu. Badane rody wierzby energetycznej nie różniły się zachwaszczeniem (tab. 5). 
Tabela 1. Liczba gatunków chwastów w czerwcu

Table 1. Number of weed species in June

\begin{tabular}{|c|c|c|c|c|c|c|}
\hline \multirow{2}{*}{$\begin{array}{c}\text { Sposób uprawy } \\
\text { Cultivation system }\end{array}$} & \multirow{2}{*}{$\begin{array}{l}\text { Lata } \\
\text { Years }\end{array}$} & \multicolumn{2}{|c|}{$\begin{array}{l}\text { Krótkotrwałe } \\
\text { Annual weeds }\end{array}$} & \multicolumn{2}{|c|}{$\begin{array}{c}\text { Wieloletnie } \\
\text { Perennial } \\
\end{array}$} & \multirow{2}{*}{$\begin{array}{l}\text { Razem } \\
\text { Together }\end{array}$} \\
\hline & & $\begin{array}{l}\text { jednoliścienne } \\
\text { grass weeds }\end{array}$ & $\begin{array}{c}\text { dwuliścienne } \\
\text { broadleaf weeds }\end{array}$ & $\begin{array}{c}\text { jednoliścienne } \\
\text { grass weeds }\end{array}$ & $\begin{array}{c}\text { dwuliścienne } \\
\text { broadleaf weeds }\end{array}$ & \\
\hline \multirow{3}{*}{$\begin{array}{l}\text { Bez koniczyny białej } \\
\text { Without white clover }\end{array}$} & 2010 & 3 & 10 & 1 & 1 & 15 \\
\hline & 2011 & 2 & 6 & 1 & 4 & 13 \\
\hline & 2012 & 0 & 5 & 2 & 6 & 13 \\
\hline \multirow{3}{*}{$\begin{array}{l}\text { Z koniczyną białą } \\
\text { With white clover }\end{array}$} & 2010 & 2 & 8 & 1 & 0 & 11 \\
\hline & 2011 & 0 & 1 & 1 & 1 & 3 \\
\hline & 2012 & 0 & 1 & 1 & 1 & 3 \\
\hline
\end{tabular}

Tabela 2. Liczba gatunków chwastów we wrześniu

Table 2. Number of weed species in September

\begin{tabular}{|c|c|c|c|c|c|c|}
\hline \multirow{2}{*}{$\begin{array}{l}\text { Sposób uprawy } \\
\text { Cultivation system }\end{array}$} & \multirow{2}{*}{$\begin{array}{l}\text { Lata } \\
\text { Years }\end{array}$} & \multicolumn{2}{|c|}{$\begin{array}{l}\text { Krótkotrwałe } \\
\text { Annual weeds }\end{array}$} & \multicolumn{2}{|c|}{$\begin{array}{l}\text { Wieloletnie } \\
\text { Perennial }\end{array}$} & \multirow{2}{*}{$\begin{array}{l}\text { Razem } \\
\text { Together }\end{array}$} \\
\hline & & $\begin{array}{l}\text { jednoliścienne } \\
\text { grass weeds }\end{array}$ & $\begin{array}{c}\text { dwuliścienne } \\
\text { broadleaf weeds }\end{array}$ & $\begin{array}{l}\text { jednoliścienne } \\
\text { grass weeds }\end{array}$ & $\begin{array}{c}\text { dwuliścienne } \\
\text { broadleaf weeds }\end{array}$ & \\
\hline \multirow{3}{*}{$\begin{array}{l}\text { Bez koniczyny białej } \\
\text { Without white clover }\end{array}$} & 2010 & 4 & 7 & 1 & 2 & 14 \\
\hline & 2011 & 4 & 6 & 1 & 5 & 16 \\
\hline & 2012 & 3 & 5 & 1 & 8 & 17 \\
\hline \multirow{3}{*}{$\begin{array}{l}\text { Z koniczyną białą } \\
\text { With white clover }\end{array}$} & 2010 & 3 & 4 & 1 & 0 & 8 \\
\hline & 2011 & 0 & 1 & 1 & 1 & 3 \\
\hline & 2012 & 0 & 1 & 1 & 1 & 3 \\
\hline
\end{tabular}

Tabela 3. Najczęściej występujące chwasty w czerwcu

Table 3. The most common weeds in June

\begin{tabular}{|c|c|c|c|c|}
\hline $\begin{array}{c}\text { Sposób uprawy } \\
\text { Cultivation system }\end{array}$ & $\begin{array}{l}\text { Lata } \\
\text { Years }\end{array}$ & $\begin{array}{l}\text { Nazwa gatunkowa } \\
\text { Name of species }\end{array}$ & $\begin{array}{c}\text { Liczba chwastów } \\
\text { na } 1 \mathrm{~m}^{2} \\
\text { Number of weeds } \\
\text { per } 1 \mathrm{~m}^{2}\end{array}$ & $\begin{array}{c}\text { Ilościowość w skali } \\
\text { Brauna-Blanqueta* } \\
\text { Quantity on a scale } \\
\text { Braun-Blanquet* }\end{array}$ \\
\hline 1 & 2 & 3 & 4 & 5 \\
\hline \multirow{3}{*}{$\begin{array}{l}\text { Bez koniczyny białej } \\
\text { Without white clover }\end{array}$} & 2010 & $\begin{array}{l}\text { Echinochloa crus-galli (L.) P.B. } \\
\text { Setaria glauca (L.) P.B. } \\
\text { Chenopodium album L. } \\
\text { Polygonum lapathifolium L. } \\
\text { P. nodosum Pers } \\
\text { Thlaspi arvense L. } \\
\text { Anagallis arvensis L. } \\
\text { Elymus repens (L.) Gould }\end{array}$ & $\begin{array}{r}42,8 \\
29,4 \\
12,8 \\
4,0 \\
2,3 \\
1,7 \\
0,2 \\
0,1\end{array}$ & $\begin{array}{l}2 \\
2 \\
1 \\
+ \\
+ \\
+ \\
\mathrm{r} \\
\mathrm{r}\end{array}$ \\
\hline & 2011 & $\begin{array}{l}\text { Conyza canadensis (L.) Cronquist } \\
\text { Elymus repens (L.) Gould } \\
\text { Vicia hirsuta (L.) S.F. Gray } \\
\text { Stelaria media Vill. } \\
\text { Taraxacum officinale F.H. Wigg. } \\
\text { Polygonum lapathifolium L. } \\
\text { Solidago virgaurea L. } \\
\text { Echinochloa crus-galli (L.) P.B. } \\
\text { Artemisia vulgaris L. }\end{array}$ & $\begin{array}{r}140,3 \\
24,7 \\
7.0 \\
5,3 \\
1,0 \\
0,5 \\
0,3 \\
0,2 \\
0,1\end{array}$ & $\begin{array}{l}2 \\
2 \\
1 \\
1 \\
\mathrm{r} \\
\mathrm{r} \\
\mathrm{r} \\
\mathrm{r}\end{array}$ \\
\hline & 2012 & $\begin{array}{l}\text { Elymus repens (L.) Gould } \\
\text { Taraxacum officinale F.H. Wigg. } \\
\text { Vicia hirsuta (L.) S.F. Gray } \\
\text { Chamerion angustifolium (L.) Holub } \\
\text { Achillea millefolium L. } \\
\text { Populus alba L. }\end{array}$ & $\begin{array}{r}79,0 \\
5,3 \\
3,3 \\
0,3 \\
0,3 \\
0,1\end{array}$ & $\begin{array}{l}3 \\
1 \\
+ \\
\mathrm{r} \\
\mathrm{r} \\
\mathrm{r}\end{array}$ \\
\hline
\end{tabular}




\begin{tabular}{|c|c|c|c|c|}
\hline 1 & 2 & 3 & 4 & 5 \\
\hline \multirow{3}{*}{$\begin{array}{l}\text { Z koniczyną białą } \\
\text { With white clover }\end{array}$} & 2010 & $\begin{array}{l}\text { Echinochloa crus-galli (L.) P.B. } \\
\text { Polygonum nodosum Pers } \\
\text { Chenopodium album L. } \\
\text { Setaria glauca (L.) P.B. }\end{array}$ & $\begin{array}{r}18,4 \\
5,2 \\
4,4 \\
1.0\end{array}$ & $\begin{array}{l}1 \\
1 \\
+ \\
\mathrm{r}\end{array}$ \\
\hline & 2011 & $\begin{array}{l}\text { Elymus repens (L.) Gould } \\
\text { Helianthus tuberosus L. }\end{array}$ & $\begin{array}{l}6,3 \\
0,1\end{array}$ & $\begin{array}{l}1 \\
\mathrm{r}\end{array}$ \\
\hline & 2012 & $\begin{array}{l}\text { Elymus repens (L.) Gould } \\
\text { Helianthus tuberosus L. }\end{array}$ & $\begin{array}{r}72,7 \\
1,3\end{array}$ & $\begin{array}{l}2 \\
+\end{array}$ \\
\hline
\end{tabular}

*Skala Brauna-Blanqueta obejmuje 5 stopni: 5 - rośliny pokrywają $75-100 \%$ danej powierzchni, 1 - mniej niż 5\%, + - do 5 szt., r - do 1 szt. The Braun-Blanquet scale included a five-point scale to express the degree of presence of a plant. For example: 5 - constantly present in $75-100 \%$ of the areas, $1-$ rare in $5 \%$ of the areas, +- up to 5 pieces of plants, $r-$ do 1 piece

Tabela 4. Najczęściej występujące chwasty we wrześniu

Table 4. The most common weeds in September

\begin{tabular}{|c|c|c|c|c|}
\hline $\begin{array}{c}\text { Sposób uprawy } \\
\text { Cultivation system }\end{array}$ & $\begin{array}{l}\text { Lata } \\
\text { Years }\end{array}$ & $\begin{array}{l}\text { Nazwa gatunkowa } \\
\text { Name of species }\end{array}$ & $\begin{array}{c}\text { Liczba chwastów } \\
\text { na } 1 \mathrm{~m}^{2} \\
\text { Number of weeds } \\
\text { per } 1 \mathrm{~m}^{2}\end{array}$ & $\begin{array}{l}\text { Ilościowość w skali } \\
\text { Brauna-Blanqueta* } \\
\text { Quantity on a scale } \\
\text { Braun-Blanquet* }\end{array}$ \\
\hline \multirow{3}{*}{$\begin{array}{l}\text { Bez koniczyny białej } \\
\text { Without white clover }\end{array}$} & 2010 & $\begin{array}{l}\text { Echinochloa crus-galli (L.) P.B. } \\
\text { Setaria glauca (L.) P. B. } \\
\text { Chenopodium album L. } \\
\text { Galinsoga parviflora Cav. } \\
\text { Thlaspi arvense L. } \\
\text { Polygonum lapathifolium L. } \\
\text { Anagallis arvensis L. } \\
\text { Elymus repens (L.) Gould }\end{array}$ & $\begin{array}{r}32,0 \\
22,7 \\
12.0 \\
10,7 \\
1,2 \\
1,0 \\
0,3 \\
0,2 \\
\end{array}$ & $\begin{array}{l}3 \\
2 \\
1 \\
1 \\
+ \\
\mathrm{r} \\
\mathrm{r} \\
\mathrm{r}\end{array}$ \\
\hline & 2011 & $\begin{array}{l}\text { Conyza canadensis (L.) Cronquist } \\
\text { Setaria glauca (L.) P.B. } \\
\text { Digitaria sanguinalis (L.) Scop. } \\
\text { Vicia hirsuta (L.) S.F. Gray } \\
\text { Taraxacum officinale F.H. Wigg. } \\
\text { Solidago virgaurea L. } \\
\text { Echinochloa crus-galli (L.) P.B. } \\
\text { Artemisia vulgaris L. }\end{array}$ & $\begin{array}{r}111,7 \\
30,0 \\
23,7 \\
22,0 \\
1,2 \\
0,2 \\
0,2 \\
0,1 \\
\end{array}$ & $\begin{array}{l}3 \\
1 \\
1 \\
1 \\
+ \\
\mathrm{r} \\
\mathrm{r} \\
\mathrm{r}\end{array}$ \\
\hline & 2012 & $\begin{array}{l}\text { Elymus repens (L.) Gould } \\
\text { Conyza canadensis (L.) Cronquist } \\
\text { Setaria glauca (L.) P.B. } \\
\text { Taraxacum officinale F.H. Wigg. } \\
\text { Achillea millefolium L. } \\
\text { Chamerion angustifolium (L.) Holub } \\
\text { Populus alba L. }\end{array}$ & $\begin{array}{r}31,3 \\
4,7 \\
3,7 \\
1,7 \\
0,4 \\
0,3 \\
0,1 \\
\end{array}$ & $\begin{array}{l}2 \\
+ \\
+ \\
+ \\
\mathrm{r} \\
\mathrm{r} \\
\mathrm{r}\end{array}$ \\
\hline \multirow{3}{*}{$\begin{array}{l}\text { Z koniczyną białą } \\
\text { With white clover }\end{array}$} & 2010 & $\begin{array}{l}\text { Echinochloa crus-galli (L.) P.B. } \\
\text { Galinsoga parviflora Cav. } \\
\text { Chenopodium album L. } \\
\text { Setaria glauca (L.) P.B. }\end{array}$ & $\begin{array}{r}13,6 \\
8,0 \\
6,0 \\
3,0\end{array}$ & $\begin{array}{l}1 \\
1 \\
1 \\
+\end{array}$ \\
\hline & 2011 & $\begin{array}{l}\text { Elymus repens (L.) Gould } \\
\text { Helianthus tuberosus L. }\end{array}$ & $\begin{array}{l}4,0 \\
0,1\end{array}$ & $\begin{array}{l}+ \\
\mathrm{r}\end{array}$ \\
\hline & 2012 & $\begin{array}{l}\text { Elymus repens (L.) Gould } \\
\text { Helianthus tuberosus L. } \\
\text { Conyza canadensis }(\mathrm{L} .) \text { Cronquist }\end{array}$ & $\begin{array}{r}77,3 \\
1,3 \\
1,0\end{array}$ & $\begin{array}{l}2 \\
+ \\
\mathrm{r}\end{array}$ \\
\hline
\end{tabular}

*Skala Brauna-Blanqueta obejmuje 5 stopni: 5 - rośliny pokrywają $75-100 \%$ danej powierzchni, 1 - mniej niż 5\%, + - do 5 szt., r - do 1 szt. The Braun-Blanquet scale included a five-point scale to express the degree of presence of a plant. For example: 5 - constantly present in $75-100 \%$ of the areas, 1 - rare in $5 \%$ of the areas, +- up to 5 pieces of plants, $r-$ do 1 piece

W latach 2010-2011 żywa ściółka istotnie ograniczała suchą masę i liczbę chwastów. W trzecim roku badań, we wrześniu zachwaszczenie na poletkach kontrolnych było niższe niż w uprawie współrzędnej, ale różnice te nie były istotne (tab. 6). Korzystny wpływ koniczyny białej w pierwszym roku badań na ograniczenie zachwaszczenia można wytłumaczyć jej konkurencją o światło i warunki siedliska. W następnych latach pokrycie gleby przez koniczynę zmniejszyło się, ale prawdopodobnie zwiększyła się ilość azotu dostarczonego przez bakterie brodawkowe do gleby. Mógł się on przyczynić do wystąpienia istotnych różnic w wysokości roślin, w uprawie współrzędnej i kontroli, w trzecim roku badań (tab. 6). 
Tabela 5. Wpływ koniczyny białej na zachwaszczenie badanych rodów wierzby

Table 5. Effect of white clover on weed infestation in the following clones of willow

\begin{tabular}{|c|c|c|c|c|c|c|c|}
\hline \multirow[t]{2}{*}{$\begin{array}{c}\text { Sposób uprawy } \\
\text { Cultivation system }\end{array}$} & \multirow[t]{2}{*}{$\begin{array}{l}\text { Ród } \\
\text { Clon }\end{array}$} & \multicolumn{2}{|c|}{$\begin{array}{c}\text { Sucha masa chwastów } \\
\text { na } 1 \mathrm{~m}^{2}[\mathrm{~g}] \\
\text { Dry weight of weeds } \\
\text { per } 1 \mathrm{~m}^{2}[\mathrm{~g}]\end{array}$} & \multicolumn{2}{|c|}{$\begin{array}{c}\text { Liczba chwastów } \\
\text { na } 1 \mathrm{~m}^{2} \\
\text { Number of weeds } \\
\text { per } 1 \mathrm{~m}^{2}\end{array}$} & \multicolumn{2}{|c|}{$\begin{array}{c}\text { Zawartość wody } \\
\text { w świeżej masie chwastów } \\
\text { The water content } \\
\text { in the fresh weight of weeds } \\
{[\%]}\end{array}$} \\
\hline & & $\begin{array}{l}\text { czerwiec } \\
\text { June }\end{array}$ & $\begin{array}{l}\text { wrzesień } \\
\text { September }\end{array}$ & $\begin{array}{l}\text { czerwiec } \\
\text { June }\end{array}$ & $\begin{array}{l}\text { wrzesień } \\
\text { September }\end{array}$ & $\begin{array}{l}\text { czerwiec } \\
\text { June }\end{array}$ & $\begin{array}{l}\text { wrzesień } \\
\text { September }\end{array}$ \\
\hline \multirow{3}{*}{$\begin{array}{l}\text { Bez koniczyny białej } \\
\text { Without white clover }\end{array}$} & 1047 & 49 & 169 & 123 & 208 & 78,0 & 68,1 \\
\hline & 1052 & 93 & 126 & 136 & 202 & 77,7 & 62,4 \\
\hline & 1057 & 81 & 180 & 146 & 213 & 78,3 & 62,7 \\
\hline \multirow{3}{*}{$\begin{array}{l}\text { Z koniczyną białą } \\
\text { With white clover }\end{array}$} & 1047 & 12 & 69 & 32 & 114 & 75,6 & 64,5 \\
\hline & 1052 & 21 & 57 & 57 & 97 & 77,3 & 67,8 \\
\hline & 1057 & 29 & 66 & 39 & 60 & 74,0 & 58,4 \\
\hline \multicolumn{2}{|l|}{ NIR $(0,05)-\operatorname{LSD}(0.05)$} & r.n. & r.n. & r.n. & r.n. & r.n. & 9,34 \\
\hline \multicolumn{8}{|c|}{ Średnie dla czynników - Means for the factors } \\
\hline $\begin{array}{l}\text { Bez koniczyny białej } \\
\text { Without white clover }\end{array}$ & & 74 & 158 & 135 & 208 & 78,0 & 64.4 \\
\hline $\begin{array}{l}\mathrm{Z} \text { koniczyną biała } \\
\text { With white clover }\end{array}$ & & 21 & 64 & 43 & 90 & 75,6 & 63.6 \\
\hline \multicolumn{2}{|l|}{$\operatorname{NIR}(0,05)-\operatorname{LSD}(0.05)$} & 16,1 & 47,0 & 47,5 & 42,0 & r.n. & r.n. \\
\hline & 1047 & 30 & 119 & 78 & 161 & 76,8 & 66,3 \\
\hline & 1052 & 57 & 91 & 97 & 150 & 77,5 & 65,1 \\
\hline & 1057 & 55 & 123 & 93 & 137 & 76,2 & 60,5 \\
\hline \multicolumn{2}{|l|}{$\operatorname{NIR}(0,05)-\operatorname{LSD}(0.05)$} & r.n. & r.n. & r.n. & r.n. & r.n. & 4,20 \\
\hline \multicolumn{2}{|l|}{2010} & 76 & 178 & 73 & 248 & 77,8 & 65,2 \\
\hline \multicolumn{2}{|l|}{2011} & 38 & 94 & 109 & 117 & 70,8 & 65,9 \\
\hline \multicolumn{2}{|l|}{2012} & 28 & 61 & 86 & 82 & 81,8 & 60,8 \\
\hline \multicolumn{2}{|l|}{$\operatorname{NIR}(0,05)-\operatorname{LSD}(0.05)$} & 19,7 & 57,6 & r.n. & 51,4 & 3,85 & r.n. \\
\hline
\end{tabular}

r.n. - różnica nieistotna - not significant difference

Tabela 6. Wpływ koniczyny białej na zachwaszczenie i wysokość wierzby (średnie dla współdziałania systemu uprawy i lat) Table 6. Effect of white clover on weed infestation in the following clones of willow (means for interaction tillage system and years)

\begin{tabular}{|c|c|c|c|c|c|c|}
\hline \multirow{2}{*}{$\begin{array}{l}\text { Sposób uprawy } \\
\text { Cultivation system }\end{array}$} & \multirow{2}{*}{$\begin{array}{l}\text { Lata } \\
\text { Years }\end{array}$} & \multicolumn{2}{|c|}{$\begin{array}{l}\text { Sucha masa chwastów na } 1 \mathrm{~m}^{2}[\mathrm{~g}] \\
\text { Dry weight of weeds per } 1 \mathrm{~m}^{2}[\mathrm{~g}]\end{array}$} & \multicolumn{2}{|c|}{$\begin{array}{l}\text { Liczba chwastów na } 1 \mathrm{~m}^{2} \\
\text { Number of weeds per } 1 \mathrm{~m}^{2}\end{array}$} & \multirow{2}{*}{$\begin{array}{c}\text { Wysokość } \\
\text { wierzby } \\
\text { Height of willow } \\
\text { [cm] }\end{array}$} \\
\hline & & $\begin{array}{l}\text { czerwiec } \\
\text { June }\end{array}$ & $\begin{array}{l}\text { wrzesień } \\
\text { September }\end{array}$ & $\begin{array}{l}\text { czerwiec } \\
\text { June }\end{array}$ & $\begin{array}{l}\text { wrzesień } \\
\text { September }\end{array}$ & \\
\hline \multirow{3}{*}{$\begin{array}{l}\text { Bez koniczyny białej } \\
\text { Without white clover }\end{array}$} & 2010 & 116 & 271 & 95 & 328 & 95 \\
\hline & 2011 & 63 & 160 & 210 & 230 & 202 \\
\hline & 2012 & 42 & 43 & 99 & 65 & 336 \\
\hline \multirow{3}{*}{$\begin{array}{l}\text { Z koniczyną białą } \\
\text { With white clover }\end{array}$} & 2010 & 36 & 84 & 50 & 168 & 95 \\
\hline & 2011 & 12 & 28 & 7 & 4 & 236 \\
\hline & 2012 & 15 & 80 & 72 & 99 & 412 \\
\hline \multicolumn{2}{|l|}{ NIR $(0,05)-\operatorname{LSD}(0.05)$} & 27,9 & 81,4 & 82,2 & 72,7 & 34,8 \\
\hline
\end{tabular}

W uprawie bez koniczyny białej sucha masa chwastów była ujemnie skorelowana $\mathrm{z}$ wysokością roślin wierzby, a współczynnik Pearsona był znacznie silniejszy niż przy uprawie współrzędnej (rys. 1,2).
Po trzech latach od założenia doświadczenia wyższe plony świeżej masy uzyskano w uprawie współrzędnej (tab. 7). Inne wyniki (za wyjątkiem 3 miesiąca) po przyoraniu koniczyny białej na plantacji Salix sachalinensis Schmidt. i S. discolor Muhl. otrzymali Arevalo i wsp. 


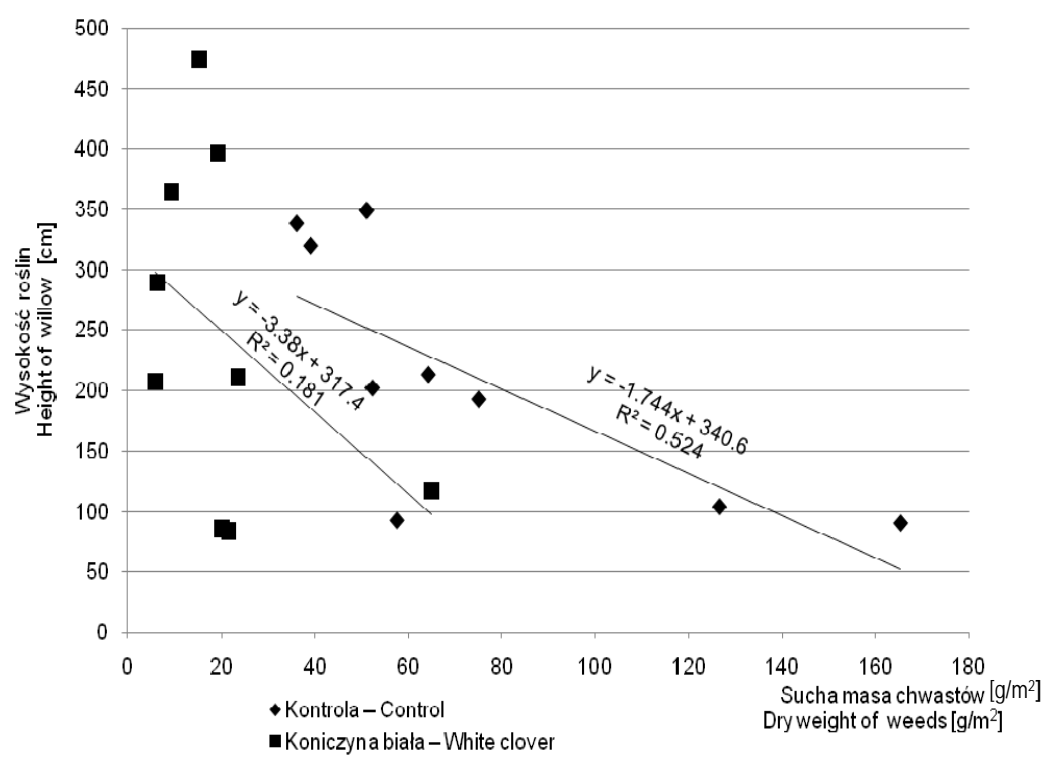

Rys. 1. Zależność wysokości roślin wierzby od suchej masy chwastów w czerwcu, w latach 2010-2012

Fig. 1. Dependence willow plant height of dry weight of weeds in June in 2010-2012

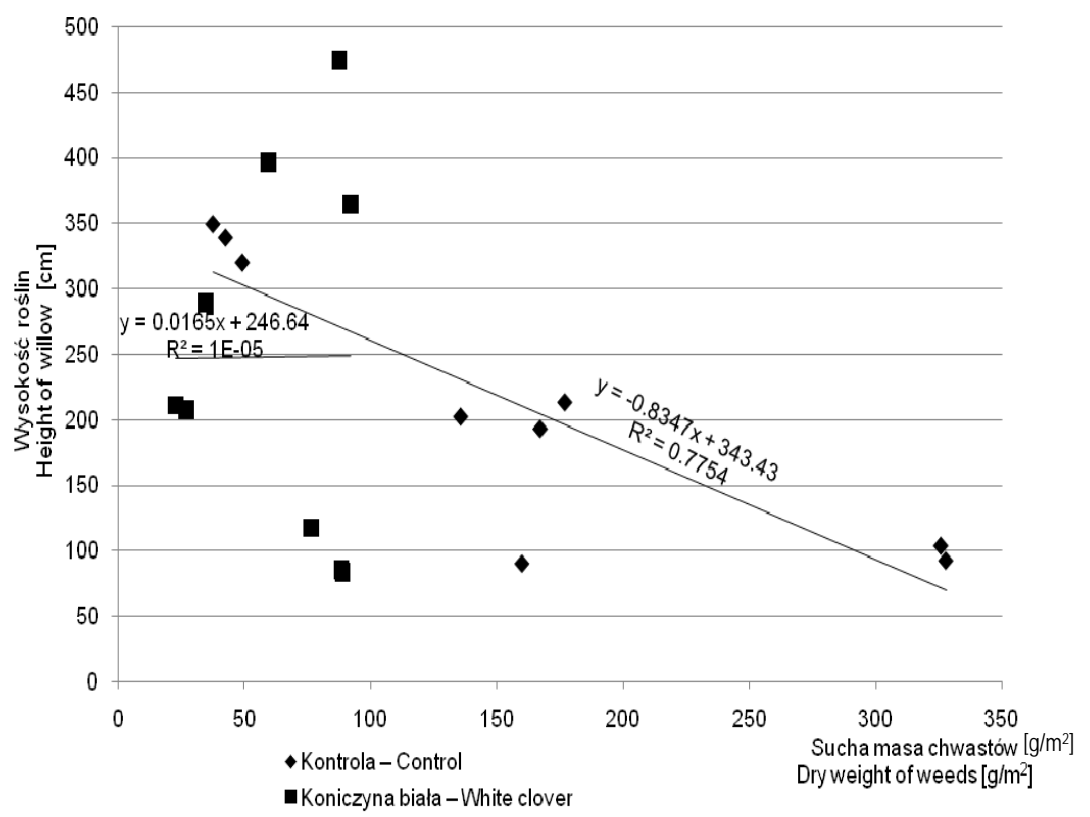

Rys. 2. Zależność wysokości roślin wierzby od suchej masy chwastów we wrześniu, w latach 2010-2012

Fig. 2. Dependence willow plant height of dry weight of weeds in September in 2010-2012

Tabela 7. Wpływ koniczyny białej na plon świeżej masy i wysokość badanych rodów wierzby (średnie dla czynników) Table 7. Effect of white clover on yield fresh weight and height following willow clones (means for the factors)

\begin{tabular}{|c|c|c|c|}
\hline $\begin{array}{l}\text { Sposób uprawy } \\
\text { Cultivation system }\end{array}$ & $\begin{array}{l}\text { Ród } \\
\text { Clon }\end{array}$ & $\begin{array}{l}\text { Plon świeżej masy wierzby ze zbioru } \\
\text { po } 3 \text { latach }[\mathrm{t} / \mathrm{ha}] \\
\text { Fresh weight yield of willow of the harvest } \\
\text { after } 3 \text { years }[\mathrm{t} / \mathrm{ha}]\end{array}$ & $\begin{array}{c}\text { Wysokość wierzby } \\
\text { Height of willow } \\
{[\mathrm{cm}]}\end{array}$ \\
\hline Bez koniczyny białej - Without white clover & & 25,7 & 211 \\
\hline Z koniczyną białą - With white clover & & 36,7 & 248 \\
\hline \multicolumn{2}{|l|}{$\operatorname{NIR}(0,05)-\operatorname{LSD}(0.05)$} & 4,14 & 20,1 \\
\hline & 1047 & 32,4 & 215 \\
\hline & 1052 & 26,7 & 216 \\
\hline & 1057 & 34,5 & 258 \\
\hline \multicolumn{2}{|l|}{ NIR $(0,05)-\operatorname{LSD}(0.05)$} & 2,18 & 15,0 \\
\hline
\end{tabular}


Tabela 8. Wpływ koniczyny białej na plon świeżej masy i wysokość badanych rodów wierzby (średnie dla współdziałania systemu uprawy i rodów)

Table 8. Effect of white clover on yield fresh weight and height following willow clones (means for interaction tillage system and clones)

\begin{tabular}{l|c|c|c}
\hline $\begin{array}{c}\text { Sposób uprawy } \\
\text { Cultivation system }\end{array}$ & $\begin{array}{c}\text { Ród } \\
\text { Clon }\end{array}$ & $\begin{array}{c}\text { Plon świeżej masy wierzby ze zbioru po 3 latach } \\
\text { Fresh weight yield of willow of the harvest after 3 years } \\
\text { [t/ha] }\end{array}$ & $\begin{array}{c}\text { Wysokość wierzby } \\
\text { Height of willow } \\
{[\mathrm{cm}]}\end{array}$ \\
\hline Bez koniczyny białej & 1047 & 30,6 & 211 \\
Without white clover & 1052 & 22,2 & 201 \\
\hline Z koniczyną biała & 1057 & 24,2 & 222 \\
With white clover & 1047 & 34,1 & 219 \\
& 1052 & 31,2 & 230 \\
NIR $(0,05)-$ LSD $(0.05)$ & 1057 & 44,8 & 294 \\
\hline
\end{tabular}

(2005). W badaniach własnych średnia wysokość roślin wierzby, które uprawiano razem z koniczyną białą była wyższa niż na poletkach kontrolnych, ale istotne różnice wystąpiły tylko w przypadku rodu 1052 i 1057 (tab. 8). W uprawie współrzędnej rośliny rodu 1052 były nieznacznie wyższe niż rodu 1047. W przypadku kontroli wystapiła sytuacja odwrotna. Wyższe pędy rodu 1047 niż 1052 zaobserwowano w badaniach innych autorów (Styszko i wsp. 2008; Styszko i wsp. 2010).

\section{Wnioski / Conclusions}

1. Wprowadzenie żywej ściółki przyczyniło się istotnie do ograniczenia suchej masy chwastów i ich liczby w ciągu dwóch pierwszych lat badań.

2. Wysokość roślin i plon świeżej masy wierzby rodu 1052 i 1057 były wyższe w uprawie współrzędnej.

3. W kolejnych latach malała sucha masa chwastów oraz ich liczba we wrześniu.

4. W zachwaszczeniu wraz $\mathrm{z}$ upływem czasu malała liczba gatunków chwastów krótkotrwałych, a wzrastał udział gatunków wieloletnich.

\section{Literatura / References}

Arevalo C.B.M., Drew A.P., Volk T.A. 2005. The effect of common Dutch white clover (Trifolium repens L.), as a green manure, on biomass production, allometric growth and foliar nitrogen of two willow clones. Biomass and Bioenergy 29: 22-31.

Korniak T. 2007. Zachwaszczenie upraw wierzby w północno-wschodniej części Polski. Pam. Puł. 145: 141-149.

Miziniak W. 2008. Wpływ herbicydów na wybrane odmiany wierzby energetycznej (Salix vinimalis). [Effect of herbicides on some cultivars of Salix vinimalis]. Prog. Plant Prot./Post. Ochr. Roślin 48 (1): 301-306.

Rola J., Sekutowski T., Rola H., Badowski M. 2006. Problem zachwaszczenia plantacji wierzby krzewiastej (Salix vinimalis). [Weed infestation problem of Salix viminalis plantations]. Prog. Plant Prot./Post. Ochr. Roślin 46 (1): 81-87.

Rola J., Sekutowski T., Rola H., Badowski M. 2007. Bioróżnorodność zbiorowisk chwastów na plantacjach wierzby krzewiastej (Salix viminalis L.) na terenie województwa dolnośląskiego i opolskiego. Pam. Puł. 145: 165-175.

Skrzypczak W., Szulc P., Waligóra H. 2009. Wpływ pielęgnacji mechanicznej na zachwaszczenie plantacji wikliny. J. Res. Appl. Agric. Eng. 54 (4): 94-97.

Sowiński J. 1988. Wpływ herbicydów oraz dodatkowego spulchniania międzyrzędzi na zachwaszczenie, wzrost i plonowanie wikliny. Cz. I. Wpływ na zachwaszczenie, wzrost i plonowanie wikliny w pierwszym roku uprawy. Rocz. Nauk Rol. A (107), 3: $187-203$.

Styszko L., Fijałkowska D., Sztyma M. 2008. Obserwacje rozwoju wierzby energetycznej w 2007 roku. Rocz. Ochr. Środ. 10: $425-432$.

Styszko L., Fijałkowska D., Sztyma M. 2010. Wpływ warunków pozyskania biomasy na odrastanie pędów wierzby energetycznej w czteroletnim cyklu. Rocz. Ochr. Środ. 12: 339-350.

Szczukowski S., Tworkowski J., Wiwart M. 1996. Wiklina - uprawa i uszlachetnianie. Wyd. ATR, Olsztyn, 30 ss.

Trąba Cz., Majda J., Wolański P. 2007. Zbiorowiska roślinne towarzyszące plantacjom Salix cordata „Americana” Hort. i Salix viminalis L. na terenie województwa podkarpackiego. Pam. Puł. 145: 221-231.

Winiarska S., Kołota E. 2004. Przydatność wybranych gatunków roślin jako żywych ściółek w uprawie pora oraz ocena ich wartości nawozowej. Rocz. AR Poznań CCCLVI: 225-232.

Wojciechowski W., Zawieja J., Sowiński J. 2011. Różnorodność gatunkowa chwastów w zależności od pielęgnacji wierzby w pierwszym roku po posadzeniu w warunkach Sudetów. [Diversity of weed species composition depending on nursing willow plantation during the first year after planting in the Sudety Mountains]. Prog. Plant Prot./Post. Ochr. Roślin 51 (1): 492-496. 